\title{
GAMBARAN SERTA KESESUAIAN TERAPI DIARE PADA PASIEN DIARE AKUT YANG MENJALANI RAWAT INAP DI RSUD SLEMAN
}

\author{
Imam Jayanto $^{1 *}$, Vitarani Dwi Ananda Ningrum ${ }^{2)}$, Wahyuni ${ }^{2)}$ \\ 1) Program Studi Farmasi, FMIPA, Universitas Sam Ratulangi, Manado 95115 \\ 2) Jurusan Farmasi Fakultas MIPA Universitas Islam Indonesia
}

Korespondensi : jayimam@yahoo.co.id

\begin{abstract}
Diarrhea defined as bowel movements that does not form or in a liquid consistency with increasing frequency. According to the data of World Health Organization (WHO), diarrhea is the number one cause of infant mortality in the world. This research aims to describe the pharmacological use of antidiarrheal therapy and rehydration in the management hospitalized diarrheal patients in Sleman District Hospital according with SPM in this case using the SPM Sardjito Hospital, Yogyakarta. This research carried out with the observational analytic cross sectional design (cross-sectional) and a prospective collecting data on patients hospitalized diarrhea in Sleman District Hospital during June to September 2012. Sampling used purposive sampling techniques that meets inclusion criteria. Type of data in this research is secondary data and primary data taken from the demographic data and patient medical records as well as interviews with relevant patients. Analysis the research data done in 2 ways, that is using descriptive analysis to describe the demographic distribution of diarrhea in Sleman District Hospital. Then continued with the inferential analysis using SPSS test a logistics Binner and chi-square test. The results are was 34\% the suitability treatment in the form of antibiotic therapy for diarrhea; was $16.68 \%$ in the form of diarrhea rehydration therapy; was $100 \%$ in the form of antidiarrheal therapy.
\end{abstract}

Keywords : Acute diarrhea, therapeutic efficacy, binary logistic

\begin{abstract}
ABSTRAK
Diare didefinisikan sebagai buang air besar yang tidak berbentuk atau dalam konsistensi cair dengan frekuensi yang meningkat. Menurut data Badan Kesehatan Dunia (WHO), diare adalah penyebab nomor satu kematian balita di seluruh dunia. Penelitian ini bertujuan untuk mengetahui gambaran terapi farmakologi penggunaan antidiare dan rehidrasi dalam penanganan pasien diare rawat inap di RSUD Sleman dengan mengacu pada SPM RSUP Sardjito, Yogyakarta. Penelitian ini dilakukan secara observasional dengan rancangan analitik cross sectional (potong lintang) dan pengambilan data secara prospektif pada pasien diare rawat inap di RSUD Sleman selama Juni - September 2012. Pengambilan sampel menggunakan teknik purposive sampling yang telah memenuhi kriteria inklusi. Jenis data yang digunakan dalam penelitian ini adalah data sekunder dan data primer yang diambil dari data demografi dan data rekam medik pasien serta wawancara langsung dengan pasien terkait. Analisis data hasil penelitian dilakukan dengan 2 cara, yaitu memakai analisis deskriptif untuk mengetahui gambaran distribusi demografi pasien diare di RSUD Sleman. Lalu dilanjutkan dengan analisis inferensial dengan memakai uji SPSS berupa logistik binner dan uji chi-square. Hasilnya terdapat kesesuaian terapi sebesar 34\% yang berupa terapi antibiotik untuk diare; sebesar $16,68 \%$ yang berupa terapi rehidrasi diare; sebesar $100 \%$ yang berupa terapi antidiare.
\end{abstract}

Kata Kunci : Diare akut, kemanjuran terapi, logistik biner 


\section{PENDAHULUAN}

Diare didefinisikan sebagai suatu perubahan kebiasaan buang air besar bagi individu yang mengakibatkan tinja secara substansial lebih sering terjadi (Anonim, 2005). Diare menyebabkan hilangnya air dan mineral (elektrolit, seperti kalium) dan dapat menyebabkan dehidrasi. Anakanak, dan terutama bayi bisa mengalami dehidrasi jauh lebih cepat dibandingkan orang dewasa, sehingga sangat penting bahwa cairan diganti (Anonim, 2010). Diare adalah buang air besar dalam bentuk cair lebih dari tiga kali dalam sehari, biasanya disertai sakit dan kejang perut. Diare yang terjadi biasanya bisa sembuh sendiri dan tidak berbahaya, tetapi diare yang berat bisa menyebabkan dehidrasi dan bisa membahayakan jiwa. Dehidrasi adalah suatu keadaan dimana tubuh kekurangan cairan yang dapat berakibat kematian, terutama pada anak / bayi jika tidak segera diatasi (Anonim, 2006).

Diare sampai saat ini masih merupakan masalah kesehatan, tidak saja di negara berkembang tetapi juga di negara maju. Di Inggris 1 dari 5 orang menderita diare infeksi setiap tahunnya dan 1 dari 6 orang pasien yang berobat ke praktek umum menderita diare infeksi. Di Amerika Serikat keluhan diare menempati peringkat ketiga dari daftar keluhan pasien pada ruang praktek dokter, sementara beberapa rumah sakit di Indonesia data menunjukkan bahwa diare akut karena infeksi, menempati peringkat pertama s/d keempat (Prastowo, 2009). Penyakit diare adalah salah satu penyebab utama morbiditas dan kematian di negara berkembang dan bertanggung jawab atas kematian jutaan orang setiap tahun. Ada banyak bukti epidemiologi dan eksperimental yang berkaitan dengan penyakit diare akut di seluruh dunia, yang merupakan salah satu penyebab utama kematian pada bayi (Rajamanickam dkk, 2010).

Pengobatan pada gastroenteritis biasanya ialah minum cairan yang cukup, termasuk pada penderita yang muntah, harus minum sedikit demi sedikit untuk mengatasi dehidrasi sehingga muntahnya terhenti. Jika muntah berlangsung terus dan terjadi dehidrasi berat, mungkin diperlukan infus cairan dan elektrolit. Untuk pencegahan diare, biasakan mencuci tangan dengan sabun sebelum makan maupun sesudah buang air besar serta masaklah makanan dengan baik dan benar (Anonim, 2011).

Strategi terapi untuk diare ialah tindakan preventif terlebih dahulu seperti penanganan makanan yang ketat, sanitasi, air, dan praktek-praktek kebersihan lingkungan yang dapat mencegah penularan. Jika diare menyebabkan penyakit lain, diperlukan pengendalian kondisi primer. Jika preventif tidak berhasil dan diare masih terjadi, tujuan terapi selanjutnya ialah mengelola diet, mencegah pengeluaran air dan elektrolit juga gangguan asambasa yang berlebihan, memberikan obat-obat simtomatik, mengobati penyebab yang bisa disembuhkan serta mengelola gangguan "sekunder" penyebab diare. Aneka obat telah digunakan untuk mengobati serangan diare. Obat-obat ini dikelompokkan menjadi beberapa kategori, yaitu antimotilitas, adsorben, senyawa antisekresi, antibiotik, enzim, dan mikroflora usus. Biasanya obat ini tidak untuk kuratif melainkan paliatif (Dipiro dkk, 2008).

\section{METODE PENELITIAN Rancangan Penelitian}

Penelitian ini dilakukan secara observasional dengan rancangan analitik cross sectional (potong lintang) dan pengambilan data secara prospektif pada pasien diare rawat inap di RSUD 
Sleman, Yogyakarta. Pengambilan data dilakukan dengan cara penelusuran data rekam medik perawatan pasien serta mengunjungi bangsal-bangsal dimana pasien tersebut dirawat yang kemudian digunakan sebagai alat untuk menelusuri demografi pasien dan riwayat pengobatan pasien.

\section{Tempat dan Waktu Penelitian}

Penelitian ini dilaksanakan pada selang 4 bulan yaitu bulan Juni September 2012, sedangkan tempat penelitian dilakukan di RSUD Sleman dengan diagnosis pasien diare yang rawat inap memakai kuisioner serta data rekam medis pasien.

\section{Populasi}

Populasi target ialah seluruh pasien diare yang rawat inap di RSUD Sleman, Yogyakarta. Populasi terjangkau adalah pasien diare yang rawat inap dengan umur minimal 1 tahun di RSUD Sleman, Yogyakarta pada bulan Juni - September 2012. Pengambilan sampel menggunakan teknik purposive sampling yang telah memenuhi kriteria inklusi serta diharapkan dapat menjadi sampel representative. Kriteria inklusi \& eksklusi dari sampel meliputi :

1. Pasien dengan diagnosis diare.

2. Mendapatkan terapi farmakologi.

3. Menjalani rawat inap minimal 2 hari di RSUD Sleman.

4. Mempunyai catatan rekam medis lengkap

Kriteria eksklusi terdiri dari :

1. Umur $<1$ tahun \& tanpa terkait penyakit tertentu.

2. Menjalani rawat inap tetapi pada saat penelitian dimulai, pasien sudah sembuh atau meninggal pada rentang waktu penelitian

\section{HASIL DAN PEMBAHASAN}

Dianalisis data yang sudah didapat berdasarkan kajian literatur dimana kemungkinan makna klinis bisa terjadi yang mana meliputi :

\section{Analisis deskriptif}

Analisis dilakukan agar mengetahui gambaran distribusi demografi pasien diare akut di RSUD Sleman, Yogyakarta dengan cara menghitung persentase jumlah masing-masing variabel, kemudian menyajikannya dalam bentuk diagram.

\section{Analisis inferensial}

Dalam hal ini, dibagi menjadi 2 kategori dari hasil terapi yang didapat yaitu berhasil dan tidak berhasil. Terapi berhasil terjadi jika pasien mengalami penurunan frekuensi $\mathrm{BAB}$ yang bisa dilihat dari rekam medik yaitu $\leq 3$ kali sehari, sedangkan terapi tidak berhasil jika pasien masih memiliki frekuensi $\mathrm{BAB}>3$ kali sehari atau tidak ada perubahan dan penurunan gejala. Dalam analisis ini memakai uji SPSS yang meliputi:

a. Analisis faktor-faktor yang mempengaruhi keberhasilan terapi diare akut memakai analisis regresi Binner Logistic.

b. Analisis hubungan antara tingkat keberhasilan terapi dengan faktor-faktor yang mempengaruhi keberhasilan terapi diare akut memakai analisis statistik nonparametrik dengan model uji chi-square.

\section{Terapi Farmakologi Pasien Diare Akut}

Terapi farmakologi dalam penyembuhan pasien diare akut di RSUD Sleman terdiri dari terapi rehidrasi dan terapi antidiare serta terapi antibiotik. Selain agen penyebab, terapi inisial haruslah ada rehidrasi. Kecuali jika pasien koma atau mengalami dehidrasi, rehidrasi oral dengan larutan elektrolit berisi glukosa itu lebih baik. Formulasi standard yang direkomendasikan oleh Organisasi Kesehatan Dunia (WHO), atau formula 
yang otomatis bisa menurunkan osmolaritas untuk anak-anak bisa dipakai untuk daerah yang miskin sumber daya alam dan ini bernilai dalam dunia industri untuk bayi, lansia, pasien immunocompromized serta semua orang dengan diare cairan berlebih. Para orang dewasa yang memiliki diare akut di negara berkembang, termasuk travelers, seharusnya mendorong untuk minum cairan garam dalam sup dan biskuit/kerupuk asin. Selain itu, pada kejadian diare pasien akan diikuti dengan muntah ataupun demam dimana merupakan kejadian yang mengikuti diare \& sering terjadi pada pasien di RSUD Sleman. Kemungkinan, hal itu terjadi karena infeksi bakteri atau virus $\&$ muntah biasanya sembuh dalam waktu 24 jam dari onset awal. Menurut Medical Advice and Treatment for Vomiting (2006) bahwa dalam kebanyakan kasus muntah dan diare, tidak ada obat yang dibutuhkan karena biasanya muntah dan diare bisa sembuh sendiri (self limiting). Tetapi di RSUD Sleman, setiap pasien diare rawat inap diberikan terapi antimuntah seperti ondansetron atau domperidon menurut dosis masing-masing. Padahal menurut SPM juga disebutkan bahwa kejadian muntah pada diare cukup "mengikuti" terapi rehidrasi dan tidak boleh diberikan antiemetik sehingga pengobatan muntah tersebut tidak sesuai.

Dalam hal ini, diare juga diikuti kejadian demam pada pasiennya dan sering terjadi di RSUD Sleman juga. Demam terjadi karena memang merupakan gejala dalam diare \& disebabkan oleh kejadian dehidrasi pasien diare yang mana suhu tubuh akan susah turun serta reaksi melawan penyakit akibat kuman atau virus yang menyerang dimana diare akut sendiri banyak diakibatkan oleh infeksi. Sebagian besar (sekitar 90\%) diare disebab- kan oleh infeksi rotavirus. Menurut Saepulloh (2005) bahwa infeksi virus rota biasanya terjadi 1 hari sebelum timbul gejala klinis setelah 3 hari yang ditandai dengan demam, sakit perut, dan muntah-muntah diikuti dengan diare yang berbau sangat tidak sedap selama 5-8 hari. Walaupun infeksi virus rota yang berdampak pada gangguan pencernaan, frekuensinya tidak banyak menyerang orang dewasa. Di RSUD Sleman, pengobatan demam pada diare diberikan terapi parasetamol, sedangkan menurut Saepulloh (2005) diberikan vaksin yang virus rota sesuai standard WHO. Tetapi pada SPM pengatasan panas sudah merupakan tatalaksana demam pada diare asalkan memeriksa fisik, kadar elektrolit, KGD terlebih dahulu. Sehingga terapi ini sesuai dengan SPM.

Seperti yang diketahui, diare terjadi jika ada peningkatan kadar air, volume atau frekuensi mekanisme usus. Diare akut biasanya terjadi $<14$ hari (Anonim, 2007). Diare akut dikelompokkan berdasarkan :

1. Diare Non Inflamasi

Pengeluaran tinja yang cair dan tubuh terasa mual, muntah, serta nyeri diperut. Dalam hal ini, antibiotik tidak selalu diperlukan. Pasien akan berangsur-angsur baik dalam beberapa hari (Anonim, 2007).

2. Diare Inflamasi

Pengeluaran tinja sedikit mengandung darah dimana kondisi pasien demam dan mengalami sakit perut yang parah. Hasil lab akan menunjukkan adanya darah dan selsel nanah serta terbukti tinja mengandung bakteri seperti Shigella, Salmonela, E. Coli, serta Campilobacter. Antibiotik diperlukan untuk melawan bakteri tersebut (Anonim, 2007). Antibiotik "hanya diberikan" atas indikasi yang jelas seperti tabel dibawah ini 
Tabel 1. Terapi Antibiotik Pada Pasien Diare Akut RSUD Sleman Bulan Juni September 2012

\begin{tabular}{|l|c|c|c|}
\hline \multicolumn{1}{|c|}{ Jenis Antibiotik } & $\begin{array}{c}\text { Jumlah } \\
\text { Terapi }\end{array}$ & $\begin{array}{c}\text { Persentase } \\
(\mathbf{\%})\end{array}$ & Keterangan \\
\hline Amoksisilin & 1 & 2 & Kurang Sesuai \\
\hline Ampisilin & 1 & 2 & Kurang Sesuai \\
\hline Gentamisin & 1 & 2 & Kurang Sesuai \\
\hline Kotrimoksazol (TMP-SMZ) & 3 & 6 & Sesuai \\
\hline Metronidazol & 13 & 28 & Sesuai \\
\hline Sefiksim & 8 & 17 & Kurang Sesuai \\
\hline Sefotaksim & 19 & 41 & Kurang Sesuai \\
\hline Sefriakson & 1 & 2 & Kurang Sesuai \\
\hline Total & 47 & 100 & Kurang Sesuai \\
\hline
\end{tabular}

Sebagian besar jenis antibiotik yang diberikan kepada pasien diare akut di RSUD Sleman adalah Sefotaksim (40,42\%). Sefotaksim dan seftriakson, keduanya merupakan Sefalosporin generasi III. Pemberian sefalosporin pada anak-anak harus dipantau karena fungsi ginjal yang belum sempurna dapat menyebabkan efek nefrotoksik. Selain itu, masih banyak efek samping lain yang membahayakan. Sefalosporin merupakan kelompok antibiotika yang mempunyai spektrum luas dan berkhasiat bakterisid dalam fase pertumbuhan kuman, menghambat sintesis dinding sel dan mengaktifasi enzim autolitik pada dinding sel, namun antibiotik jenis ini tidak ada dalam SPM.

Terbanyak selanjutnya adalah jenis antibiotik metronidazol (27,66 \%). Walaupun jumlah pasien keseluruhan hanya 36 orang, pemberian antibiotik bisa saja lebih dari 1 buah kepada 1 pasien. Hal ini bisa saja menimbulkan keadaan interaksi obat. Misalnya ada pasien yang mendapat injeksi sefotaksim \& injeksi sefiksim akan menimbulkan efek berupa saling mendukung dimana mereka ialah antibiotik golongan betalaktam (sefalosporin generasi ketiga) dimana sefalosposrin generasi ketiga bisa digunakan jika ada kecurigaan bakteri batang gram negatif (Asih dkk, 2006) contohnya E. Coli. Pertama, bisa kita liat dari antibiotik yang diapakai dan sesuai dg SPM yaitu Metronidazol dan TMP-SMX. Dari SPM diatas, bisa disimpulkan bahwa pemberian TMPSMX kepada pasien yang menderita kolera (disentri) sedangkan pemberian metronidazol kepada pasien yang terkena infkesi amoeba.

Kedua, untuk pemberian antibiotik selain TMP-SMX \& metronidazol, dikarenakan untuk menghindari infeksi nosokomial yang didapat selama pasien dirawat di rumah sakit. Patogen yang sering terlibat berupa bakteri nosokomial yang resisten terhadap antibiotika yang beredar di rumah sakit. Biasanya ialah bakteri enterik golongan gram batang negatif seperti E. Coli, Klebsiella sp., Proteus sp. Pada pasien yang sudah dulu mendapat terapi sefalosporin generasi ketiga, biasanya dijumpai bakteri enterik yang lebih bandel seperti Citrobacter sp., Serratia sp., Enterobacter $s p$. Pemilihan antibiotik untuk pneumonia nosokomial memerlukan kejelian karena sangat dipengaruhi pola resistensi antibiotika baik invitro maupun invivo di rumah sakit. Sehingga antibiotika yang dapat digunakan tidak heran bila berbeda antara satu rumah sakit dengan rumah sakit yang lain (Anonim, 2005). Evaluasi mikrobiologi pada pasien rumah sakit dengan paparan terbaru antibiotik dalam perkembangan diare 
siapapun, seharusnya fokus pada diagnosis ketoksikan dari $C$. difficile, yang paling umum diketahui menyebabkan diare nosokomial. Uji terhadap patogen lain pada pasien yang dirawat di rumah sakit lebih dari 72 jam itu dianjurkan kecuali merebakna wabah atau pada pasien berumur 65 tahun atau lebih dengan kondisi kesehatan yang sudah ada, pasien dengan infeksi HIV, pasien dengan neutropenia dan pasien dengan dugaan penularan infeksi usus sistemik (Thielman dkk, 2004).

Misalnya amoksisilin yang mana antibiotik ini digunakan untuk infeksi oleh bakteri gram negatif seperti $H$. Influenza, E. Coli, P. Mirabilis, Salmonella). Amoksisilin termasuk antibiotik spektrum luas dalam kelompok penisilin (Anonim, 2006). Amoksisilin harus digunakan dengan hati-hati bagi yang memiliki penyakit saluran cerna, terutama kolitis, karena efeknya terhadap keseimbangan flora usus. Kebanyakan efek samping cukup ringan, namun meningkat menurut dosis dan lama penggunaan. Kebanyakan reaksi yang merugikan disebabkan oleh fakta bahwa amoksisilin tidak hanya membunuh bakteri patogen tetapi juga bakteri baik yang merupakan flora alami usus. Efek samping potensialnya meliputi mual dan muntah, sakit perut, diare, gangguan pencernaan (dispepsia), dubur gatal dan reaksi alergi (Anonim, 2013). Jadi pemberian amoksisilin pada pasien tersebut, bisa memperparah keadaan diarenya.

Oleh karena hal itu, antibiotik disarankan untuk diare akut dengan catatan :

1. Pemilihan antibiotik harus mengingat frekuensi resistensi antibiotik setempat.

2. Antibiotik menjamin keberhasilan terapi, tetapi dapat memperpendek masa sakit dan emngeradikasi organisme pada kasus berat.
3. Jika tidak dimungkinkan pemeriksaan laboratorium untuk menentukan penyebab, maka adanya darah dalam tinja (bentuk disentri) bisa dijadikan indikasi pemberian antibiotik (Anonim, 2000).

4. Terdapat bukti infeksi akut.

5. Diare akut tersebut kemungkinan mengancam nyawa.

6. Perlunya mengurangi pembuangan bakteri melalui tinja untuk mencegah infeksi tersebut menular kepada orang lain.

7. Pasien mengalami diare kronik atau akut setelah bepergian ke luar negeri akhir-akhir ini (Anonim, 2007).

Untuk menilai dehidrasi, perhatikan keadaan fisik dan kesadaran pasien, denyut nadi, tekanan darah, ada atau tidaknya hipotensi postural, selaput lendir dan air mata, mata cekung, turgor kulit, pengisian kapiler, dan tekanan vena leher. Rehidrasi biasanya mungkin dengan larutan rehidrasi oral yaitu 3,5 gr natrium klorida; 2,5 gr natrium bikarbonat; 1,5 gr kalium klorida, dan 20 gr polimer glukosa atau glukosa (seperti sukrosa) dalam 1 liter air yang mengandung larutan dengan $90 \mathrm{mM}$ natrium, kalium 20mm, 80 klorida $\mathrm{mM}$, $30 \mathrm{mM}$ bikarbonat, dan $111 \mathrm{mM}$ glukosa. Atau, satu sendok garam meja dan delapan sendok teh gula per liter air berisi $86 \mathrm{mM}$ natrium untuk yang secangkir jus jeruk atau dua buah pisang dapat ditambahkan untuk kalium (Thielman dkk, 2004).

Dehidrasi terjadi ketika seorang anak atau bayi kehilangan dan tidak adanya replacing cairan dan elektrolit. Tingkat keparahan dehidrasi paling akurat dikaji dalam hal penurunan berat badan sebagai persentase dari total berat badan (sebelum episode dehidrasi). Bayi dan anak-anak dengan diare disertai atau tanpa muntah dan tidak segera mengisi cairan secara memadai bisa 
mengalami dehidrasi sangat cepat dan konsekuensinya dapat berakibat serius bila dehidrasi tidak segera ditangani. Dalam sebuah sistematic review tentang ketepatan gejala, tanda dan tes laboratorium ialah dasar bagi penilaian keparahan dehidrasi pada anak-anak berusia antara 1 bulan sampai 5 tahun seperti waktu pengisian kapiler, turgor kulit dan pola pernapasan menjadi ukuran yang paling penting dari dehidrasi. Ulasan ini menemukan juga bahwa meskipun laporan orangtua tentang pengeluaran urin normal bisa menurunkan kemungkinan terjadinya dehidrasi, riwayat pengeluaran urin yang sedikit tidak memperbesar kemungkinan mengalami dehidrasi. Para reviewer menemukan bahwa ada kurangnya literatur berkualitas tinggi untuk mengevaluasi indikator klinis dari dehidrasi pada anak-anak serta pengujian dehidrasi yang tidak akurat (Anonim, 2006).
Dalam pengatasan dehidrasi, dimana pembagian dehidrasi sesuai tabel II, maka tatalaksananya dibedakan menjadi tiga rencana yaitu rencana $A$ untuk pasien tanpa dehidras, rencana $\mathrm{B}$ untuk pasien dengan dehidrasi ringan dan dehidrasi sedang, rencana $\mathrm{C}$ untuk pasien dengan dehidrasi berat (Anonim, 1990).

1. Penderita diare akut tanpa dehidrasi (kelompok A) terapi bisa berupa rawat jalan dan diberikan cairan berupa oralit atau larutan rumah tangga.

2. Penderita diare akut dehidrasi ringan atau sedang (kelompok B) : penderita diobservasi diruang Rehidrasi Oral selama \pm 4 jam.

Penderita diare akut dehidrasi berat (kelompok C) : diberikan terapi cairan i.v. berupa Ringer Laktat (RL) 100 $\mathrm{mg} / \mathrm{kg}$ bb. Kalau tidak, bisa diberikan larutan D5- ${ }^{1} / 2$ S (Anonim, 2000).

Tabel 2. Pemberian Rehidrasi Untuk Pasien Diare Akut RSUD Sleman Bulan Juni - September 2012

\begin{tabular}{|l|c|c|c|l|}
\hline Derajat Dehidrasi & Terapi Rehidrasi & Jumlah & Persentase & \multicolumn{1}{|c|}{ Kesesuaian } \\
\hline \multirow{4}{*}{ Tanpa } & Tanpa & 1 & $2,78 \%$ & Sesuai \\
\cline { 2 - 5 } & Oralit & 2 & $5,56 \%$ & Tidak Sesuai \\
\cline { 2 - 5 } & Infus & 12 & $33,33 \%$ & Tidak Sesuai \\
\hline \multirow{4}{*}{ Ringan } & Tanpa & 0 & $0,00 \%$ & - \\
\cline { 2 - 5 } & Oralit & 2 & $5,56 \%$ & Sesuai \\
\cline { 2 - 5 } & Infus & 10 & $27,78 \%$ & Tidak Sesuai \\
\hline \multirow{4}{*}{ Sedang } & Tanpa & 0 & $0,00 \%$ & - \\
\cline { 2 - 5 } & Oralit & 1 & $2,78 \%$ & Sesuai \\
\cline { 2 - 5 } & Infus & 6 & $16,67 \%$ & Tidak Sesuai \\
\hline \multirow{3}{*}{ Berat } & Tanpa & 0 & $0,00 \%$ & - \\
\cline { 2 - 6 } & Oralit & 0 & $0,00 \%$ & - \\
\cline { 2 - 6 } & Infus & 2 & $5,56 \%$ & Sesuai \\
\cline { 2 - 5 } & Jumlah Pasien & 36 & $100,00 \%$ & \\
\hline
\end{tabular}

Temuan data menunjukkan bahwa hampir seluruh pasien penderita diare akut di RSUD Sleman baik tanpa dehidrasi maupun yang tergolong dehidrasi berat diberikan cairan rehidrasi melalui infuse pada hari pertama. Terapi ini tidak sesuai dengan arahan dari Kementrian Kesehatan Indonesia, dimana pasien tanpa dehidrasi bisa diberikan terapi cairan berupa oralit atau larutan rumah 
tangga. Sedangkan untuk penderita diare dengan dehidrasi ringan sampai sedang, cairan rehidrasi diberikan secara oral. Terapi yang diberikan pada pasien penderita diare akut diberikan beberapa obat antidiare, zinc dan probiotik untuk mempersingkat lama diare. Berikut jenis-jenis antidiare yang digunakan dalam terapi pasien diare di RSUD Sleman :

Tabel 3. Pemberian Antidiare Untuk Pasien Diare Akut RSUD Sleman Bulan Juni - September 2012

\begin{tabular}{|l|c|c|}
\hline \multicolumn{1}{|c|}{ Jenis Antidiare } & Jumlah Terapi & Persentase \\
\hline Attapulgit & 1 & $2 \%$ \\
\hline Loperamid & 3 & $7 \%$ \\
\hline Oralit & 1 & $2 \%$ \\
\hline Probiotik (Lactobacillus) & 11 & $26 \%$ \\
\hline Sukralfat & 2 & $5 \%$ \\
\hline Zinc & 25 & $58 \%$ \\
\hline Total & 43 & $100 \%$ \\
\hline
\end{tabular}

Berdasarkan diagram di atas dapat diketahui bahwa jenis antidare yang paling banyak digunakan adalah Zinc $(58 \%)$, dan diikuti dengan pemberian probiotik (26\%). Hasil ini sesuai dengan penelitian Christie Manoppo (2010) yang menyatakan bahwa lama diare pada pasien yang mendapat pengobatan dengan zinc saja adalah 4,85 hari; dengan zinc dan probiotik hidup 4,16 hari; dengan zinc dan probiotik mati ialah 5,77 hari; dengan probiotik mati saja ialah 5,86 hari. Menurut Van Niel (2002) bahwa suplementasi Lactobacillus selama diare akut telah didemonstrasikan memiliki dampak yang menguntungkan baik pada durasi diare maupun tingkat keparahan sakit.

Pada penelitian di Peru oleh Penny ME. (2004) melaporkan bahwa tingkat kesakitan lebih tinggi dengan suplementasi zinc yang ditambahkan multivitamin dan mineral dibandingkan hanya suplementasi zinc.

\section{KESIMPULAN}

Berdasarkan hasil pembahasan, dapat diambil kesimpulan sebagai berikut:

1. Gambaran terapi farmakologi dalam penanganan pasien diare rawat inap di RSUD Sleman adalah antibiotic Sefotaksim (41\%), diberikan cairan rehidrasi melalui infu $\mathrm{s}$ dari tanpa derajat dehidrasi sampai derajat dehidrasi berat, dengan antidiare terbanyak ialah Zinc $(58 \%)$.

2. Kesesuaian terapi diare di RSUD Sleman dengan SPM dari RSUP dr. Sardjito dalam penanganan pasien diare rawat inap serta kondisi awal frekuensi BAB pasien per hari dan kondisi dehidrasi pasien.

\section{DAFTAR PUSTAKA}

Anonim. 1990. Buku Ajar Diare, Pendidikan Medik Pemberantasan Diare, diterjemahkan oleh Sunoto. Jakarta : Ditjen PPM dan PLP Depkes RI., 21 - 23

Anonim, 2000, Komite Medik RSUP Dr. Sardjito, Standar Pelayanan Medis RSUP DR. Sardjito Buku 2, MEDIKA FK UGM, Yogyakarta.

Anonim, 2005, Evidence-Based Practice Guideline For The Management Of Diarrhea With Or Without Vomiting In Children : Ensuring Children With Diarrhea Receive The Best Possible Care, Southern Health : Australia. 
Anonim. 2005. Diarrhea Treatment Guidelines : Including New Recommendations For The Use Of ORS and Zinc Supplementation For Clinic-Based Healthcare Workers. WHO : USA Sec 3:1.

Anonim, 2005, Phamraceutical Care Untuk Penyakit Saluran Pernafasan, Dirjen Bina Kefarmasian Dan Alat Kesehatan DEPKES RI : Jakarta, hal. 27-28. 30-32. 33-39.

Anonim. 2006. Pedoman Penggunaan Obat Bebas Dan Bebas Terbatas. Direktorat Bina Farmasi Komunitas Dan Klinik, DITJEN Bina Kefarmasian Dan Alat Kesehatan, Departemen Kesehatan RI : Jakarta. Hal. 4043.

Anonim, 2006, Amoksisilin, http : / / dinkes. tasikmalayakota. go. Id / index. php/informasi-obat/211amoksisilin.html (diakses tanggal 3 Maret 2013)

Anonim, 2007, Use Antibiotics In Adults (Penggunaan Antibiotik Di Kalangan Orang Dewasa) Edisi 1, Health Promotion Board, Singapore.

Anonim. 2010.

General Recommendations Regarding Diarrhea. California Childcare Health Program, University of California. 1-2.

Anonim. 2011. Gastroenteritis, www.medicastore.com gastroenteritis.html acessed 31 Oktober 2011.

Anonim, 2011, Buletin Jendela Data \& Informasi Kesehatan Triwulan II : Situaswi Diare Di Indonesia, Jakarta : Kementerian Kesehatan RI.

Anonim, 2012, Koran Indonesia Sehat : Atasi Diare Pada Orang Dewasa Perlukah Obat?, Yudhasmara Publisher, Jakarta
Anonim, 2013, Amoksisilin : Kegunaan \& Efek Sampingnya, Majalah Kesehatan, 28 Februari 2013 (http://majalahkesehatan.com/amo ksisilin-kegunaan-dan-efeksampingnya/ diakses tanggal 3 Maret 2013)

Asih S., Retno and Landia S., and Makmuri MS., 2006, Continuing Education, Ilmu Kesehatan Anak $X X X V I$, Kapita Selekta Ilmu Kesehatan Anak VI, Divisi Respirologi Bagian Ilmu Kesehatan Anak FK UNAIR RSU Dr. Soetomo : Surabaya.

Bellido-Blasco, JB \& A. Amedo-Pena. 2011. Epidemiology of Infectious Diarrhea, Elsevier B. V., Public Health Center of Castello'n, Spain.

Binder, HJ, M.D. 1990. Pathophysiology of Acute Diarrhea, The American Journal Of Medicine., 88 (6A) : $2 \mathrm{~S}-4 \mathrm{~S}$

Dipiro, JT. et. al. 2008. Pharmacotherapy

Pathophysiologic Approach, Seventh Edition. The McGrawHill Companies : USA. Page 617 -623 .

Giannella, RA., et all. 1999. Acute Diarrhea : A Practical Review, The American Journal Of Medicine., $106: 670-676$.

Goulet O, Seidman EG. 2004. Gastrointestinal manifestation of immunodeficiency. Primary immunodeficiency disease. In: Walker WA, Goulet O, Kleinman RE, Sherman PM, Shneider BL, Sanderson IR ed. Pediatric gastrointestinal disease pathophysiology diagnosis management vol 1, 4th ed. Ontario : Allan Walker, 707-41

Green Berger, NJ., et all. 2009. Current Diagnosis \& Treatment Gastroenterology, Hepatology, Endoscopy. Mc Graw Hill : USA. 
Grimwood, Keith \& David A. Forbes. 2009. Acute And Persistent Diarrhea, Pediatr Clin $N$ Am, dipublikasikan by Elsevier Inc., $56: 1343-1361$

Harianto. 2004. Penyuluhan Penggunaan Oralit Untuk Menanggulangi Diare Di Masyarakat. Majalah Ilmu Kefarmasian Vol. 1 No. 3 April 2004.

. 2010. Pharmacological Management of Diarrhea, Gastroenterol Clin N Am, Published by Elsevier Inc., 39 : $495-507$

Karuniawati, F. 2010. Pengaruh Suplementasi Seng Dan Probiotik Terhadap Durasi Diare Akut Cair Anak, Thesis, Program Pascasarjana Magister Ilmu Biomedik, Program Pendidikan Dokter Spesialis I Ilmu Kesehatan Anak, Fakultas Kedokteran, Universitas Diponegoro, Semarang.

Ma'arij, NFN. 2009. Identifikasi Drug Related Problems (DRPs) Dalam Pengobatan Diare Pada Anak Di Instalasi rawat Inap Rumah Sakit Umum Daerah Wonogiri Tahun 2007. Skripsi. Fakultas Farmasi, Univeristas Muhammadiyah Surakarta, Surakarta.

Manoppo, Christie. 2010, Dampak Pemberian Seng Dan Probiotik Terhadap Lama Diare AkutDi Rumah Sakit DR. RD. Kandou, Manado, Sari Pediatri, 12 (1) : 17-20

Pickering, LK. 1991. Therapy For Acute infectious Diarrhea In Children, The Journal Of Pediatrics, 118 (4 part 2) : S118 S128

Prastowo, FA. 2009. Asuhan Keperawatan Tn. S Dengan Gangguan Sistem Pencernaan Diare Di Bangsal Melati RSUD Sragen, Skripsi, Fakultas Ilmu
Kesehatan

Un\$iversitas

Muhammadiyah

Surakarta,

Surakarta.

Rajamanickam, V., et all., 2010. Antidiarrheal Activity Of Dodonea viscosa Root Extracts. International Journal of Pharma and Biosciences. $1: \mathrm{Ph} 182-\mathrm{Ph}$ 185.

Rosalina I. 2007. Efikasi pemberian zinc pada diare dalam Naskah lengkap Konggres nasional III Badan Koordinasi Gastroenterologi Anak Indonesia. Penanganan optimal masalah saluran cerna dan hati pada anak. Surabaya : BKGAI.

Rossytyawati, S. 2011. Evaluasi Pengobatan Diare Pada Anak Di Instalasi Rawat Inap Rumah Sakit PKU Muhammadiyah Yogyakarta Periode Januari - Desember 2009, Skripsi, Fakultas Farmasi Universitas Gadjah Mada, Yogyakarta.

Saepulloh, Muharram. 2005. Potensi Infeksi Virus Rota Sebagai Penyakit Zoonosis Penyebab Diare Pada Anak-anak, Laporan Penelitian, Balai Penelitian Veteriner, Bogor.

Seidman E. 1995. Immune homeostasis and the gut. In: Roy CC, Silverman A, Alagille D ed. Pediatric clinical gastroenterology. 4th ed. Missouri : Mosby, 388-99

Suraatmaja, S. 2007. Kapita Selekta : Gastroenterologi Anak. Sagung Seto : Jakarta.

Taketomo, Carol K. et. all. 2000. Pediatric Dosage handbook 6th edition. USA : Lexi-comp Inc

Thielman, Nathan M. MD. MPH., Richard L. Guerrant, MD., 2004, Acute Infectious Diarrhea, The New England Journal Of Medicine, 350 (3) : 8-47 